\title{
Development of China's space program in the geopolitical region of the Asia-Pacific
}

\author{
Tatyana Vladimirovna Fedorova ${ }^{1,{ }^{*}, \text { Margarita Valerievna Novosyolova }}{ }^{1}$ \\ ${ }^{1}$ Irkutsk State University, Department of Oriental and Regional Studies of the Asia-Pacific Region, 664003, Irkutsk, Karl Marx Street 1, \\ Russia
}

\begin{abstract}
The entire world watched the space race between the USSR and the USA in the 20th century. Many countries have increased their scientific potential and developed their own space strategies. China, due to its technological backwardness, could not claim the role of a full-fledged space power. The Cultural Revolution in China put numerous space projects in stagnation. When Deng Xiaoping took office in 1978, the country revived the development of sciences and technologies; the restoration of the space program began. The country's leadership believed that peace and development were the main tasks that guided countries and communities. The article analyzes the functioning of China's space program in the AsianPacific geopolitical region. The paper is based on a wide range of sources, which made it possible to identify China's space program's features: China had to go through the main stages of space industry development in a shorter time frame, compared with the predecessor countries; the need for China to ensure security from non-traditional types of threats, including space threats, contributed to the activation of scientific and technical developments in this field.
\end{abstract}

\section{Introduction}

Space of the $21^{\text {st }}$ century is an arena where there is a clash of three countries - the United States, China and Russia - who are claiming the role of the hegemon. An advance in space exploration is one of the ways to showcase their power. However, this process cannot be considered unique, as the countries' space programs of today are focused on solving scientific, technical, military, economic and geopolitical tasks. The modern space race is not the bipolar confrontation that existed in the $20^{\text {th }}$ century, but multipolar cooperation. The economic and geopolitical changes that took place at the end of the previous century had a huge impact on the balance of power - both on earth and in space. The rise of China, India and Brazil influenced the development of the entire space industry as a whole.

Development of space technologies contributes greatly to the emergence of new types of weapons that threaten the stability and sovereignty of China, which in recent years has risen to the level of one of the world leaders. So, for China, functioning of science-intensive industries, such as the rocket and space industry, is extremely important - it will be the guarantor of the state protection in the future. This is fortified by the fact that on May 15, 2021, the landing platform of the Tianwen-1 spacecraft successfully landed on Mars, delivering the first Chinese Zhuzhong rover to the Red Planet, and in June the Shenzhou-12 manned spacecraft was launched with three cosmonauts on board.

Thus, China's space program today represents a major investment to enable Beijing to use space for its national power expansion. Thanks to space technology, the country has excellent capabilities in monitoring emergencies, be it a military confrontation or natural disaster, as well as in monitoring compliance with international treaties and arms control.

\section{Theoretical basis of the study}

The creation and development of the Chinese rocket and space program are inextricably linked with the name of the outstanding aerospace engineer Qian Xuesen, who is honored in China as the father of rocket technology. In the USA, however, he was an equally valuable researcher in rocket production in 1930-1940.

Several years later, «after graduating from China and moving to the United States, the main goal of the scientist was to study modern aviation technology and the basics of aerodynamics, he became a professor at the California Institute of Technology» [1]. In the 1940s, he helped find the Jet Propulsion Laboratory, which is one of NASA's leading space research centers [1].

The Peoples' Republic of China was formally proclaimed on October 1, 1949. And in 1955, Qian Xuesen returned to China with his family. Once in China, Qian Xuesen played a pivotal role in negotiations with the Soviet Union over the development of Chinese nuclear weapons. As the United States were increasing their nuclear potential, the leadership of China decided to develop its own atomic bomb [2]. In 1956, the USSR and the China signed an agreement on Moscow's assistance in the construction of civil and military facilities. The Soviet Union handed over «a large amount of technical documentation and equipment that were

Corresponding author: tamerlan689f17@yandex.ru 
necessary to create a complete production cycle for nuclear weapons» [3].

After the Soviet Union successfully launched the artificial Earth satellite «Sputnik-1», the President of China, Mao Zedong, formulated a goal - «two bombs, one satellite» in 1958. In order to strengthen combat power and strengthen its position on the world stage, the country planned the creation of its own atomic and hydrogen bombs, as well as the launch of a Chinese artificial Earth satellite [2].

The year 1959 was regarded as the approximate time of the satellite launch. The launch was to take place as the celebration in honor of the $10^{\text {th }}$ anniversary of foundation of the republic.

The Soviet Union helped China greatly with the provision of existing developments in the field of modification of the German V-2 rocket; China began construction of its own ballistic complex [4].

At the end of 1960, Chinese scientists tested their own ballistic missile for the first time. The Soviet Union provided tremendous assistance in this matter, providing all the relevant findings necessary for the creation of ballistic missiles. These missiles could be used in the delivery of nuclear weapons. In addition, its assistance to the developing industry consisted in material and technical support.

In 1964, China tested its own nuclear weapons for the first time. The tests took place «in the north-west of the country, in the Xinjiang Uygur Autonomous Region» [2]. In October 1966, China successfully tested the Dongfeng-2 medium-range ballistic missile carrying a nuclear warhead. In 1967, China tested a hydrogen bomb (after the USSR, the USA, and Great Britain).

In 1968, Qian Xuesen founded the Space Flight Research Center as the first step in training Chinese astronauts.

On April 24, 1970, thanks to the Changzheng-1 carrier rocket, China launched its first satellite DHN-1 (Dongfanghong-1). The Chinese satellite weighed 173 $\mathrm{kg}$., being the heaviest first satellite ever launched. It exceeded the combined mass of the first four satellites launched by the superpowers. To make the flight of the first satellite more visible to ground observers, Chinese testers added a shiny metal ring, which acted as a solar reflector, to the part of the last stage of the launch vehicle.

The launch of an artificial Earth satellite allowed China to officially join the International Space Club. China was the fifth state to carry out «launching an artificial satellite into near-earth orbit after the USSR, the USA, France and Japan» [4].

The period of the Cultural Revolution had a significant impact on all space activities in China. Most of the projects were in stagnation. When the Cultural Revolution was over, the country began to focus on the creation of geostationary communication and surveillance satellites, in the context of the development of an international espionage and intelligence system. The creation of its own complex of weapons, the main purpose of which was to defeat and disable spacecraft used for reconnaissance and navigation purposes, was a necessary measure in preserving national security. In this regard, China was developing research in functioning of anti-satellite weapons since the late 1970s.

As for China's military space projects, which constituted the majority of the total number of programs being implemented, they were mainly aimed at creating reconnaissance and cartographic satellites. At the end of November in 1975, the Changzheng- 2 carrier rocket was able to fly with the Fanhui Shi Weixing-0 (FSW-0) reentry satellite. It was equipped with special cameras for observing the Earth. This launch enabled China to master the technique of returning special capsules with photographic film.

The beginning of convergence of China and the USA was laid back in the period when Mao Zedong was in power. The year 1971 is considered the time of restoration of ties between the two countries. Henry Kissinger, a renowned American diplomat, made a trip to China with the aim of building US-China relations [5]. A few months after this visit, in 1972, Richard Nixon became the first US president to visit China. During President Nixon's visit to China, the Shanghai Communiqué was signed. It consolidated progress in normalizing the relations between China and America [5]. In 1979, China and America initiated official diplomatic relations. And the two countries made concessions to each other by signing the Agreement on Cooperation in Science and Technology. In 1983, ChinaEurope cooperation in science and space research began.

In 1984, China launched into orbit the first national geosynchronous communications satellite, Dong Fang Hong-2. In 1986, a second prototype, called Dong Fang Hong-2A, was launched into geostationary orbit. The development scientists of that time argued that the satellite was similar in technical data to the first Soviet prototype satellites of the 1960s. The next two satellites were the result of Sino-European cooperation and had new components and technical equipment.

In 1980, China successfully tested the Donfeng-5 intercontinental ballistic missile. The following year, the launch vehicle Fengbao-1 launched three satellites simultaneously for the first time.

Over the next decade, China actively expanded its international ties in the rocket and space sector. Their attention was focused primarily on the most significant space leaders of that time [6].

In the $90 \mathrm{~s}$ of the previous century, a mutual agreement was signed by China, Germany and France. A geostationary communication satellite SinoSat-1was created by the French company Aerospatiale for China. Later it was imported through the joint venture EurasSpace, which was owned by China and Germany. In 1998, the SinoSat-1 satellite was successfully launched by a Chinese rocket [7]. In addition to European satellites of various orientations, China was engaged in the import and launch of American-made satellites. It successfully collaborated with Loral, Lockheed and Hughes. With their help, it was possible to create a new communication satellite Zhongwei-1 [8].

So, China was gradually turning into a manufacturer of telecommunication satellites with European components. As a result, these technologies began to be used in the construction of national communication 
satellites, lunar probes Chang'e -1 and Chang'e-2, as well as satellites of the navigation system BeiDou.

Since the $90 \mathrm{~s}$ of the $20^{\text {th }}$ century, a commercial launch has become an integral component of the space industry. During that time, China made commercial launches for Hong Kong (AsiaSat satellite), Pakistan (BADR-A satellite) and Australia (AusSat-B1 satellite).

Since 1995, China has had a decent launch vehicle base at its disposal. In addition, the construction of spaceports was carried out throughout the country. These ports met all the necessary requirements and could provide launches of various spacecraft. In addition to the high degree of reliability of their spacecraft, China offered commercial launches, low cost of which was attractive for other countries [9].

On December 20, 1999, «China successfully launched its first unmanned spacecraft» [10] Shenzhou-1 from the Jiuquan Cosmodrome. After putting the spacecraft into low-earth orbit, it made 14 orbits around the Earth. The duration of the flight of the first Chinese unmanned spacecraft was 21 hours and 11 minutes.

In 2001, an unmanned spacecraft «Shenzhou-2» was launched to test the system for manned space flight. Compared to its predecessor, this spacecraft was distinguished by improved technical characteristics, and was an analogue of the first manned spacecraft. The device made 108 orbits around the Earth. Field mice and fruit flies on board allowed scientists to analyze the possible state of a person during the flight. Until now, the return of Shenzhou-2 to Earth causes controversy in the scientific community. The fact is that China did not provide any data regarding the landing of the ship. Foreign experts believe that the landing of the spacecraft ended in an accident due to the fact that the parachutes did not open on time.

In March 2002, the «Changzheng-2F» launch vehicle launched the third ship in the Shenzhou series, the Shenzhou-3. In December 2002, the final launch of the spacecraft was carried out before the departure of the Shenzhou-4 with a man on board. These two launches were aimed at testing human life support systems in space [10].

China became the third country to independently send a man into space. It happened in 2003, almost half a century after the Soviet Union did it for the first time. The manned spacecraft Shenzhou-5 was launched into the low-earth orbit using the Changzheng launch vehicle. A Chinese cosmonaut, Colonel of the Air Force of the People's Liberation Army, Yang Liwei was on board. During 21 hours of being in near-earth orbit, the first Chinese cosmonaut made 14 orbits around the planet [11]. This event demonstrated China's claims to take the place of one of the leaders in space technologies.

A pivotal moment for the formation of an independent Chinese space industry was the ban on the import of satellites from the United States and Europe, satellites which included US-made components.

With the restrictions imposed, China began to actively seek allies in less developed countries. As a result, a joint spacecraft of China and Brazil, the artificial satellite China-Brazil Earth Resources Satellite-1 (CBERS-1), was launched into orbit. In
2007, China launched an artificial Earth satellite for Nigeria (NigComSat-1).

In 2007, China managed to launch the Chang'e-1 lunar orbital spacecraft. This mission made China the fifth country capable of launching a spacecraft into the lunar orbit. In 2007, anti-satellite weapons were tested in China. In January 2007, the non-functioning Fengyun1C meteorological satellite was to be destroyed by a launched ballistic missile. As a result, the satellite was destroyed, and China became the third country to test anti-satellite weapons.

\section{Methodology and materials}

A complex of scientific methods constitutes the methodological basis of the given article. The methods make it possible to analyze the functioning mechanisms of China's space program in the geopolitical region of the Asia-Pacific.

The method of system-oriented analysis is implemented in studying the theoretical aspects of the space program's genesis.

The elements of influence of the outer space development on China's security system in the modern geopolitical space are revealed through the retrospection method.

The method of historical analysis helps to study materials related to the history of the Chinese space program in retrospect, which provides more accurate data on its development and formation.

Thus, the most complete picture of the Chinese space program development is provided.

\section{Results and discussion}

Today, the protection of a state implies traditional protection of state borders, as well as protection in cyberspace and outer space areas, which are relatively new. China's leadership regards the space program as one of the priority areas for ensuring the security and defense of the state in the geopolitical arena.

The space program is one of the key elements of China's effective development. «In November 2012, during a visit to «The Path to the Renaissance» exhibition at the National Museum of China, Chairmanin-Office $\mathrm{Xi}$ Jinping voiced an idea which was eventually called the Chinese Dream. It lies in the great revival of the Chinese nation, which implies restoration of the former power of the country. The benchmark for the elevation is the high level of scientific and technological development of the People's Republic of China. That is why a lot of attention in the $21^{\text {st }}$ century is paid to space technologies and achievements» [12].

China has made significant progress in a wide range of space technologies [13]. The Chinese launch vehicles and spacecraft's reliability accords with the global one. Every year, China improves and modernizes its satellite support system, which is responsible for communications, the Internet, monitoring of emergencies, etc. In addition, the country's programs for 
the study of the Moon and Mars have recently shown unprecedented success.

Despite the achievements of the Chinese space program, the international community is concerned about its military orientation. Modern space programs of the United States, Russia and China imply a combination of civilian and military components, since space is the battlefield of the future. Therefore, it is extremely important for all countries to develop effective methods of combat and defense against hostile countries in outer space [9].

China's military doctrine emphasizes the key role of outer space in winning wars. China's space policy is one of the elements of the country's foreign policy goal of restructuring the international system. China seeks to develop an advanced space program that meets national interests, which are aimed at creating a reputation as a reliable and attractive space partner [13].

The United States views China as a military competitor in space with a growing arsenal of antisatellite weapons that pose a threat to the United States' security [14]. Space is the ultimate height, the key to military success on the ground battlefield [15]. Washington believes that there is an active military component at the heart of various civilian aspects of China's space program. Numerous reports produced by the US Department of Defense say China is investing in advanced space technology, with a focus on satellite communications, intelligence, surveillance and reconnaissance, satellite navigation, and meteorology. China is also investing in unmanned, manned, and interplanetary space research. Along with its civilian space program, China continues to develop various technologies aimed at limiting or preventing the use of space assets in case of a crisis or war, which includes the creation of anti-missile and anti-satellite weapons [16].

A brief review of the recent tests conducted by Beijing shows that China is rapidly improving its counter-space program and making progress in its antisatellite systems [17]. In 2013, Beijing tested the Dong Neng-2 space interceptor, a test conducted in neargeosynchronous orbit where most of the United States satellites are located. On October 30, 2015, China tested the Dong Neng-3 transatmospheric apparatus, which is capable of destroying American satellites. According to Chinese press reports, this test was a flight test of a missile defense interceptor. In June 2016, China launched the Aolong-1 spacecraft on a Long March 7 rocket. China claims that Aolong-1 is tasked with cleaning up space debris [18]. However, other reports suggest the spacecraft is a dual-use weapon. In peacetime, the device can patrol near-earth space and clean the environment from space debris, while in wartime it is capable of destroying active satellites [19]. Some tests are known to have been carried out in 2017 and 2018.

During the military reform of China, China's Strategic Support Force (the SSF) was created in order to coordinate measures to protect the country in the field of space security. The SSF is responsible for security in outer space, cyber and electronic space. The work is carried out on the basis of satellite launch centers located at the Jiuquan, Taiyuan, Xichang, Wenchang, Xi'an cosmodromes. The SSF also includes: Main satellite communications station; Tracking and control telemetry station; Bureau of Aerospace Intelligence; Center for Aerospace Research and Development [20].

The findings obtained as a result of the active development and functioning of the national space program are also used to ensure border security. Thus, China is designing an innovative technical border guard system. In 2019, a defense and control system for the land and sea border was created on the basis of the Chinese satellite navigation system «BeiDou». The Chinese corporation NORINCO, specializing in the production of optical electronics, weapons and uniforms, received an order for the construction of ground-based continuously operating reference stations. Located along the Chinese border, they will make a quick response to emergencies possible. In addition, high-tech drones are monitoring the state border. They conduct patrols in high-risk regions, which can improve the level of protection of people's lives [21].

China has eased restrictions on governmentcontrolled industries, including space, in order to stimulate technology development. In 2020, the Chinese commercial aerospace company Galaxy Space launched the first private satellite into low-earth orbit, the main goal of which is to create satellite Internet using 5-G technologies. The Yinhe-1 satellite can cover an area of 300,000 square $\mathrm{km}$. The company reports about its plans to launch a total of 650 communications satellites into space. Satellite 5-G technologies are able to provide the Internet not only for China, but for the whole world. This is especially true for those regions of China where, due to geographic features, it is impossible to lay a ground network [22].

This startup of the private Chinese company Galaxy Space is carried out as part of China's national space program. The success of this project is considered as an achievement of space technologies, which in turn has a beneficial effect on the formation of a modern space program [22].

Another important point is the commercial aspect of Chinese astronautics. China's capabilities of building satellites and rockets that meet international standards made commercial spacecraft launches real. Their services meet the needs of the developing countries perfectly. The buyers of Chinese space technology are mainly Latin America, Africa and South Asia, namely Brazil, Nigeria and Pakistan. Buyers are attracted by the low price, high quality and relatively long service life of the satellites, which averages 15 years. In addition, China provides comprehensive support for the launch of foreign-made satellites. For example, in 2018, China launched the Pakistani satellite PAKTES-1A, which is used to predict emergencies [23].

Today, China has a huge number of bilateral agreements in the field of space cooperation. China is actively cooperating with Brazil, Venezuela, Turkmenistan, Bolivia, Thailand, Laos, Brunei and Pakistan.

Over the past few years, China has been developing its own modular space station, which will consist of 3 
blocks. The base module of the Tianhe station was launched in April 2021. The country's leadership is planning to complete the construction of the station by the year 2022. Currently, the International Space Station is operating in low-earth orbit. Creation of its own station will allow China to carry out long-term stay of astronauts in orbit. China can also sell the possibility of staying on the station to other countries, which makes it a profitable space partner.

\section{Conclusion}

China's space activities in the geopolitical region of the Asia-Pacific have recently shown an unprecedented level of growth. The main feature of the development of China's space program is going through the main stages in a shorter time frame, compared to the predecessor countries. China passed the stage from creating a nuclear bomb to creating a hydrogen one in just 2 years, while it took the USSR 4 years and the United States 7 years.

The first manned flight of a Chinese cosmonaut lasted longer than the flights of his predecessors. Compared to the Soviet Union, whose flight lasted 108 minutes, and the 15-minute flight of the United States, the flight of the astronaut from China was 21 hours.

Another criterion for comparison is the number of operational satellites of the national navigation systems. BeiDou has 42 satellites at its disposal, the American GPS navigation system has 31 satellites, and the Russian GLONASS system has only 24 satellites.

China is aiming to outdo all Asian-Pacific space competitors, namely Russia and the USA. All the successes of China's modern space program can be considered as the indicators of the strategy adopted in the 1950 s - the concept of «two bombs-one satellite», as well as Deng Xiaoping's «Innovation Policy».

In the $21^{\text {st }}$ century China continues to develop its space cooperation with other countries. The country's leadership is of the opinion that the future of Chinese astronautics lies in commercialization and innovative development. Thus, China will continue to pursue its existing space development program, which includes short and long term plans.

\section{References}

1. California institute technology. In the news. The Father of Chinese Rocketry (2016)

2. Contrary to Khrushchev: How the Chinese Tested the Atomic Bomb / Gazeta.ru (2019)

3. I.F. Kurdyukov Soviet-Chinese Relations (19171957), 466 (1959)

4. T.A. Tutnova The Development of the Chinese Space Program in the XX - XXI Centuries. History and Modernity 1, 161-181 (2014)

5. V.T. Jungblud Soviet-Chinese Split in the American Policy of Detente (1968 - 1973) Bulletin of the Nizhny Novgorod University. N.I. Lobachevsky, 1, 47-57 (2018)

6. P.B. Kamennov China's Space Program Asia and Africa Today, 9 (662), 9-16 (2012)
7. European External Action Service. EU-China Relations: Chronology (2012)

8. China's Spacecraft (2016)

9. A.B. Zheleznyakov Experience in Space Exploration by the People's Republic of China SPbSPU Scientific and Technical Bulletin, 1-2, 1321 (2012)

10. V.A. Epshtein, D.A. Bochkov, R.R. Mukhametzyanov Chinese Space Program: 60 Years of Evolution Uchen. zap. Kazan University. Ser. Humanitarian Sciences, 6 1575-1591 (2016)

11. China Internet Information Center Yang Liwei China's First Astronaut to Fly China's First Manned Space Flight (2008)

12. D.A. Bochkov China's Space Program: History and Prospects World Politics of the XXI Century: The Logic of Transformational Changes: Proceedings of Scientific. conf. 28-49 (2018)

13. V.A. Zotova Priority Areas of China's Space Program Actual problems of international relations, 9, 116-124 (2017)

14. A.S. Stepanov The Growth of China's Military Power at the Beginning of the 21st Century: Implications for the United States Russia and America in the XXI century, 3, 13 (2018)

15. E.L. Loginov Cosmos as a Strategic Priority in the Struggle for World Economic Leadership in the 21st Century National interests: priorities and security, 25, 52-61 (2010)

16. M.V. Kazanin Development of the PRC missile defense system as an element of ensuring national security Ethnic society and interethnic culture, 1, 75-86 (2021)

17. V. Ivanov China is preparing to fight in space (2019)

18. A.B. Zheleznyakov Space activities of the countries of the world in 2016 Innovations, 1, 219 (2017)

19. Zhu Yilin The Long March to Space: Satellite Communications in China Beyond the ionosphere: the development of satellite communications (1997)

20. K. Ryabov Army optimization in Chinese. The results of the People's Liberation Army reform Military review (2019).

21. Zhang Fan At Space Altitude Rossiyskaya Gazeta (2020).

22. Global Times. Chinese private satellite venture tests video call in $5 G$ speeds via satellite in space (2020)

23. RIA Novosti China put two Pakistani satellites into orbit (2018) 